\title{
A Review of Modernization: The Giresun Government House and Administrative Center
}

\author{
Selin Karaibrahimoğluำ, Özgür Demirkan ${ }^{2} \odot$, \\ ${ }^{1}$ Assistant Professor Technical Sciences Vocational School, Giresun University, Giresun, Turkey. (Principal contact for editorial \\ correspondence), Email: selin.karaibrahimoglu@giresun.edu.tr \\ ${ }^{2}$ Assistant Professor, Technical Sciences Vocational School, Giresun University, Giresun, Turkey. Email: \\ ozgur.demirkan@giresun.edu.tr
}

\begin{abstract} Purpose

The purpose of the study is to discuss the Government houses erected in the latter Ottoman period, and the administrative centers erected in time by other public buildings located around over the changes they made to the urban space and in particular over the Giresun province periodical as a necessity and symbol of administrative modernization.

Design/Methodology/Approach

Giresun's modernization experience on the periphery was conducted by a periodic reading. The Late Ottoman Period is defined as the 'First Steps of Modernization (the end of the 19th century)'; the first years of the Republic as the 'Fundamental Modernization (the early 20th century)'; today is defined as 'New Searches / Tendencies in Modernization (late 20th-21st century)'. The method of the study was determined by the collection of verbal, written, and visual data Type the design/methodology/approach of the paper here.

Findings

Buildings that were built, demolished, or changed their function in each period in the context of their own historical conditions, are part of the city's modernization process. Accordingly, the administrative center, which was erected during the Ottoman period, continued its functional and symbolic meaning for many years, but has recently started to lose this feature and its structural quality and meaning.

\section{Research Limitations/Implications}

Giresun is placed in the center of the study as a township in the Trabzon province in the late Ottoman period, and as a small port city in the Republican Age. The study focuses on the period from the late period of the Ottoman period to the present.

Originality/Value

Today, the building, which has begun to lose its effect, despite its urban, architectural, and symbolic value, should be evaluated in a way that respects the public interest and should continue to preserve its rightful value as an important part of the urban memory. This study is unique with contribution to studies related to a city that has not been placed in many urban, architectural, and historical studies and with its potential to increase sensitivity to periodical buildings in the city as one of the parts that complement the city's culture and identity.
\end{abstract}

Keywords: Administrative center, Giresun, government house, modernization 


\section{INTRODUCTION}

The standard narrative on the architectural history of the Ottoman Era that remained valid until the last quarter of the 20th century delineates 16th-century classical style as an expression of the authentic creativity and cultural purity of the Ottoman Era whilst labeling 19th-century architecture as a clear sign of social and cultural corruption as well as political bankruptcy. This description degrades the striking and sharp transformation experienced by the late-period Ottoman Era architecture to a mere imitation category. The same approach tends to label the same period as quite a complex transformation without a specific route because of all the crises, dilemmas, indecisions, whims, and contrasts it already entails (Ersoy, 2009). Yet, the trends of a period should always be assessed as per the conditions of this specific period. Within that viewpoint, Westernization efforts dominating the 19th century can be perceived as the efforts to form a new organization initiated by the Ottoman Era; sustained and stabilized by the ensuing Age of the Republic as well as the modernization process of a state. As noted by Göle (1999); modernization refers to the name of the transformation route designed on the basis of the histories and cultures of varied countries. It is infeasible that modernization histories of all geographies could overlap one hundred percent. However, it is safe to claim that they have a similar roadmap and specific breaking points could be determinants in this process.

In that sense, Turkish Modernization has an approach of which its beginning can be dated to the Reforms Period and I. Constitutional Age from various aspects. Yet, by the modern age, it had adopted novel dimensions during the Republican State. Here, the ultimate goal was to enable a social and intellectual harmony with Western Europe (Mardin, 1999). The modernization efforts that began with the Reforms Period, and maintained into the Age of the Republic, moved along a similar path in terms of methods and practices; still they also consisted of huge differences. In the Ottoman Era, initially modernization of higher institutes was the goal, while in the modernization story of the Age of Republic, the aim was not only to change these institutes, but also to transform the whole social model thus, making modernization possible (Insel, 1990). In the Ottoman-Era modernization, state formation went through a complete change, but it was still imperative to protect social order. In other words, it was allowed to continue with an organizationmodel where the old and the new coexisted again (Hanioğlu, 2016). However during the Republic modernization, when major changes were evident in the institutional and social structure, there was an ideological legitimization attempt in all aspects from the economy to private and public life, and city to architecture, as an outcome of the consistent and calculated actions of a supreme mind (Tanyeli, 2003 as cited in Çetin, 2012). In that case, the aim was to create a holistic modernization that annulled the dual organization caused by the coexistence of the traditional model that symbolizes the past in state establishments and 
1Studies on Ottoman Modernization that mostly focused on cities, practices that were executed to correct the disconnection with Ottoman rural cities and to feel its power were included in the analysis; thus, it could be viable to enrich the current approach towards this period.
A Review of Modernization: The Giresun Government House and Administrative Center

modern organizations as a symbol of the new. In the early years of the Republic, the underlying cause of defining the modernization attempt as a radical modernization is related to this approach. In that sense, it is safe to claim that making sense of the modernization history of cities through an independent viewpoint from the Ottoman Era or accepting it as new model only born out of the Age of Republic, would cause disconnections between urban and architectural narrative within the historical continuum. In the final phases of the Ottoman's legal, militaristic, administrative, cultural, and social change attempts in all the state departments must be seen as the first steps of the radical modernization moves attempted in the Age of Republic. Any period must be analyzed within the context of its authentic historical conditions, societal, economic, and social changes.

Architecture, by virtue of its interconnector dimensions that impact intercultural communication and public space patterns, is an objective narrative of this modernization process. That being said, architecture has transferred from the center to the province a huge authority with its capacity to adapt in novel programs, and needs and forms that have striking similarities which can, however, be masked under different meanings (Çelik, 2012). Hence, Government Houses and other public buildings, constructed as a mirror of novel insight and architectural system, can only adopt meaning once read on the basis of continuity of modernization. Although these structures draw similarities in terms of their functions, dimensions, and organizations in provincial centers ${ }^{1}$ they pose a much stronger statement in terms of meaning and symbolism. Defining the kind of changes they undergo during an historical process would be an eye-opener in studies that explain the modernization experience of cities by focusing on the social, economic, and spatial growth of places that they were erected. Therefore, the aim of this study is to offer a chronological analysis of Government Houses built in the Late Ottoman Era as a symbol and requirement of administrative modernization and the administrative centers formed in due course by surrounding public buildings on the basis of changes that they had already triggered in the urban space. Within that context, during the Ottoman Era, Giresun - as one of the districts of Trabzon sanjak and a minor port city in Age of Republic- has been put as the focus point in this study as a city undergoing the modernization process from the Ottoman Era until the Age of the Republic on the periphery. The government House built in the Late Ottoman Era in the city and the Administrative Center defined by the surrounding structures has been one of the determinants of urban growth as one of the major focus points during the Age of the Republic and its aftermath. Thus, the period when the Ottoman modernization efforts intensified and a new government house and administrative center were built in the city from the Late Ottoman Era to the Republic is discussed under the title "First Steps of Modernization (the end of the 19th century): Construction of Giresun Government House and Administrative Center", and the period that includes a fundamental 
and comprehensive modernization from the declaration of the Republic to the year 1980, and the traces of this development were observed in the city is discussed under the title "Fundamental Modernization in the early years of the Republic (early 20th century): The Past of the Giresun Government House-Focused Administrative Center"; and the period when the perception of modernization began to change both globally, administratively, and ideologically and how this transformation was reached much more rapidly in the urban space under the title "Changes in the Perception of Modernization (the late 20th - 21st century) of the Giresun Government House- Focused Administrative Center. The applied method was collecting verbal, print, and visual data of the said periods by following a chronological order in the analysis. Each period has been discussed in terms of its unique historical conditions; structures, and urban works that were erected, destroyed, or changed for different functions have been acknowledged as the elements that impact and define the modernization story of the Administrative Center. The growth of the Giresun Government House and Administrative Center from the past to date has been narrated in line with findings backed up with photographs, verbal, and print resources; they were drawn into the maps as schemas, and the chronological differences were comparatively analyzed. With these discussions, the change in the field and the cultural loss caused by the change is emphasized. Thus, the study will raise awareness about the building and its surrounding administrative center, which has started to lose its effectiveness despite its urban, architectural, and symbolic value today, is to be evaluated in a way that will protect the public interest and at the same time continue its existence as an important part of the urban memory. Different perspectives for the studies that will protect the social and cultural essence of a city that could not take a place much in architecture and history and contribution will be made to raise awareness regarding the protection of urban and urban identity.

\section{SPATIAL TRACES OF OTTOMAN-ERA MODERNIZATION IN THE PROVINCE: THE GOVERNMENT HOUSE AND ADMINISTRATIVE CENTER}

Upon the proclamation of the Imperial Edict of Reforms in 1839 and during the reign of II. Abdülhamit that speeded up reform movements ${ }^{2}$ and modern legal organizations, the modernization process kicked off, and a wide range of extensive changes emerged in legal, cultural, political, social and administrative spheres (Ortayl, 2008). In the age of the reforms, the Ottomans aimed to compete against Western hegemony via using the advantages already gained by their former actions. The projection of this aim within the context of the city was to build modern cities that reflect the Western lifestyle (Yerasimos, 1999). In that sense, such reforms that can be accepted as the start of the modernization process, were initially made more visible in the urban space. By replacing the old style of provincial administrations that collected unconstitutional

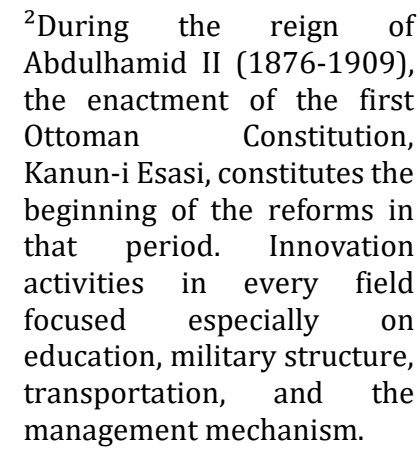


${ }^{3}$ Up until the 19 th century, the mayors appointed to the head office of the local administration generally resided in the houses reserved or hired on their behalf, but in the 19th century the state affairs performed in the houses where the administrators lived changed to their current model after the modernization movements and independent edifices started to be allocated for administrative works. For detailed information see (Çadırcl, 1997).
A Review of Modernization: The Giresun Government House and Administrative Center

taxes from the center and provincial towns with the dominance of state order and authority, it was now the aim to establish a modern, central, and direct control mechanism (İnalcık, 1962). Nevertheless, the reform movements or practices that envisaged a number of quantitative and qualitative changes in the local administrative organizations ruled by the center could find their match in a longer period though with limited content in the provincial towns when compared to the central cities. The 1870-dated Law on Cities lays the ground for building the centers in which state officials transferred from Istanbul to provincial towns would be settled and newly-identified administrative functions would coexist (Aslanoğlu, İdil et al., 1984). Within that context "new centers" defined as the Administrative Center and the inclusion of Government House, the city hall, the railroad and station house, courthouse and many other elements created an attraction zone for new service types, such as banks, hotels, and shops (Osmay, 1998). With such structures, a new spatial pattern was molded and the interrelationship between the city and its periphery adopted a new style; changes in communication channels directed the axle of consumption models and lifestyles in the domain of foreign trade and new economic relationships in cities towards a western-focused cultural structure became apparent (Tekeli, 1985). The Government Houses were built to symbolize the power of the central authority and the spatial needs of the surplus bureaucracy in provincial towns that had adopted a new status. In the entire Ottoman Empire a new architectural expression of a different monumentality and positioning principle were introduced to the cities by adopting a functional repertory unknown before. ${ }^{3}$ Thus, religious structures that contributed to describing the silhouettes of Ottoman cities in former centuries were replaced by model structures of militaristic and civilian architecture and fueled a divergence in the cities they were built by their modern associations (Avcl, 2017). In such an organizational model, the police station, the courthouse, the city hall, the post office or the clock tower are positioned as a group in the periphery public buildings. The telegraph office, prison and similar units were also built in connection with the Government Houses or were positioned in the lower floor of the state structure (Yazıcl, 2008 as cited in Çelik, 2012). In that case, these attempts to reorganize and modernize the Ottoman Era's public system point to the fact that Government Houses and administrative centers were constructed due to a functional necessity as well as an ideological content. For this reason, architectural and spatial similarities can be found that may be observed easily between the Giresun Government house, which is the focus of the study, and the government houses built in different cities such as Amasya, Bartın, Samsun, Mersin, and Safranbolu (Figure 1). However, the Giresun Government House has some unique characteristics as the most dominant element of the city silhouette in every period because it has sustained its function for many years and its location dominant over the city and its architectural features. 


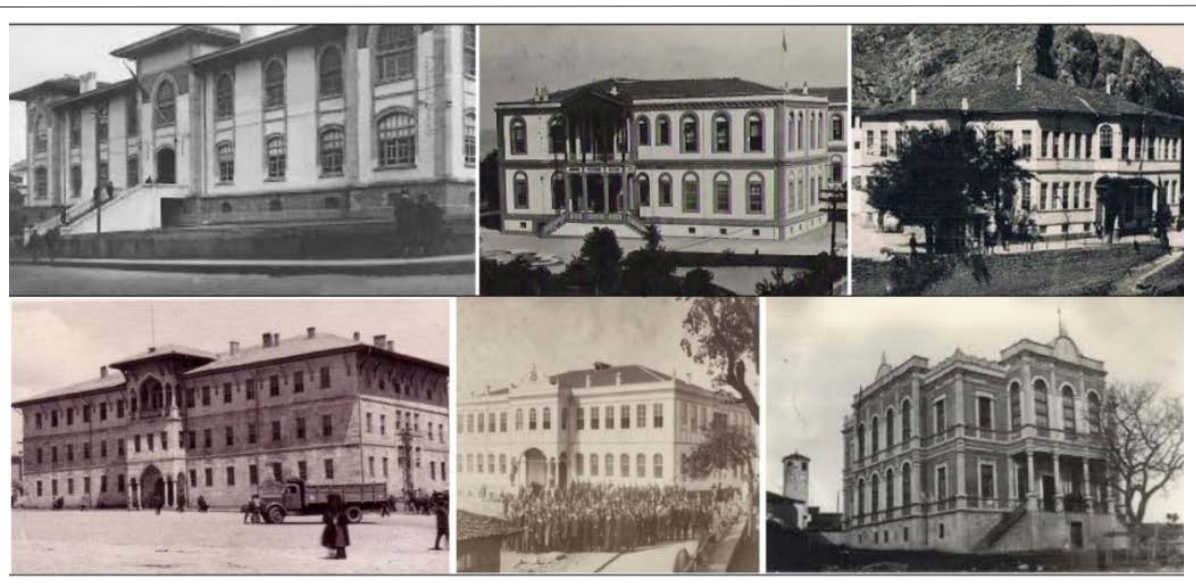

The stylistic, functional, and semantic traits in the provincial towns, and modernization process supported by public buildings and construction works were continued in a broader content during the Age of the Republic. In this period, the Government Square and Administrative Center defined by its surrounding structures are, likewise, the sites in which modernization is made apparent in a public sphere. Constructed public buildings being the symbolic expression of modern societal organization, were maintained to define urban space and steer the direction of growth. On the other hand, from the Late Ottoman Era until the early Age of the Republic, architects who molded urban space and designed public buildings in both of the periods were alike. It is thus only natural that in the early years of the Age of the Republic, urban and architectural practices reflected traces of the Late Ottoman Era and were designed in an identical architectural language. In this period that can reasonably be accepted as a transitional process, architects attempted to add an authentic identity to the architecture via new pursuits. The public buildings they designed were positioned in the city as the kind of images where this pursuit was exhibited, narrated, and promoted. Yet, the Government Houses transferred from the Ottoman Era failed to be adequate as the administrative system expanded; there was an emergent need for various organizations and new additions that could comply with unprecedented conditions. Therefore, the new Government Houses erected in the first years of the Age of the Republic were built in a way to entail a myriad of functions due to reasons such as; a lack of suitable spaces in the city or the capacity of state order to generate new functions under all circumstances (Düzenli and Taşar, 2012). Yet, in due course, governorship, courthouses, police departments, the gendarmerie. and other administrative units in these offices changed due to expanding and diversifying social needs. They were then organized as independent spaces that aligned with their own functional necessities.

Dumont and Georgeon (1996) claim that in the transition of the modernization process from the Late Ottoman Era to the Early Republic, through the modern buildings performing new functions of port cities and exhibiting a more organized urban model with the new settlements; this corresponded to a better texture of the city. By means of developed
Figure 1. At the end of the 19th century, Government Houses were built in different Anatolian cities: Trabzon (https://dede.facebook.com/ pg/TrabzondaNostalji/posts /?ref=page_internal); Samsun Government House (Ç.Koșar Archive); Sivas Government House (S.Güner Archive); Amasya Government House (S.Güner Archive); Giresun Government House (Istanbul University, Yıldız Albums, No: 90854-0027); Safranbolu Government House (Ö.Öztürk Archive). 
${ }^{4}$ In the extension of the city center; Yavuz Sultan Mosque erected, seashore, surrounding structures that remained Muslim-faith complexes and also the biggest library of Trabzon sanjak built in the city center can be accepted as such contributions. transportation, port cities could establish closer relationships with their region or interior sites. Trade operations operated through the port enabled a growth in the capacity of the urban economy and helped these cities to achieve a greater scope of development. In the same vein, it can be argued that as a port city, Giresun also followed the same growth trend. During the construction of the Government House and subsequent construction works such as courthouses, prisons, mosques, community gardens and similar public buildings that stand for the Administrative Center are also in parallel with this position.

\section{A MODERNIZATION REVIEW: GIRESUN GOVERNMENT HOUSE AND ADMINISTRATIVE CENTER}

Giresun, as a result of increasing trade operations in the 19th century, turned into one of the dynamic port-cities in the Ottoman Era. In those years it used to be a township of Trabzon sanjak. Upon its annexation to Ottoman lands, Yavuz Sultan Selim, who used to be the governor of Trabzon-centered region ${ }^{4}$ attempted to redirect the traditional settlement site that grew within the castle on to the peripheries of the castle (Emecen, 1997). In due course, as a result of being a port city situated on the Black sea shores, and an intercity connection of transportation networks that connected the region with interior sites, it significantly contributed to the vital role Giresun played in its located region. In that sense, the city moved beyond being a small sea town as of the second half of the 19th century and gained a critical trading volume with its port and institutes that supported its growth (Yüksel, 1997). Giresun, is one of the important transit axles of the region due to its road connection between the interior parts and the port. That being said, Giresun can be classified as one of the port cities that either directly or indirectly impacted economic relations that Ottomans formed with Western states. One of the most significant causes of this growth is the new engagement of Blacksea with international trade. The hazelnut started to be marketed via the port. Consequently, its value and production volume jumped and became a profitable source of income for the locals. After marketing the hazelnut to European countries, new employment opportunities flourished in the city (Yüksel and Yeşilot, 2016) and far-reaching changes that affected demographic, social and cultural format of the city took place. The first generic intervention in this process on urban space was the construction works for a GovernmentOffice focused Administrative Center. Taking all these reasons into account, and despite the relatively small population and area of the Giresun settlement, it managed to undergo a concurrent experience with the modernization process of the state from the Ottoman Era until the Age of the Republic. In parallel with the inner dynamics of the city, these practices climbed at times while falling at other times; however, during the Age of the Republic, they moved beyond spatial organizations and became a new way of living while also fueling radical changes in respect to the social aspect. Within the framework of this perspective, the 
modernization story followed through the development of the administrative center and was discussed over three periods in parallel with the modernization process of the country, including its current situation (Figure 2).
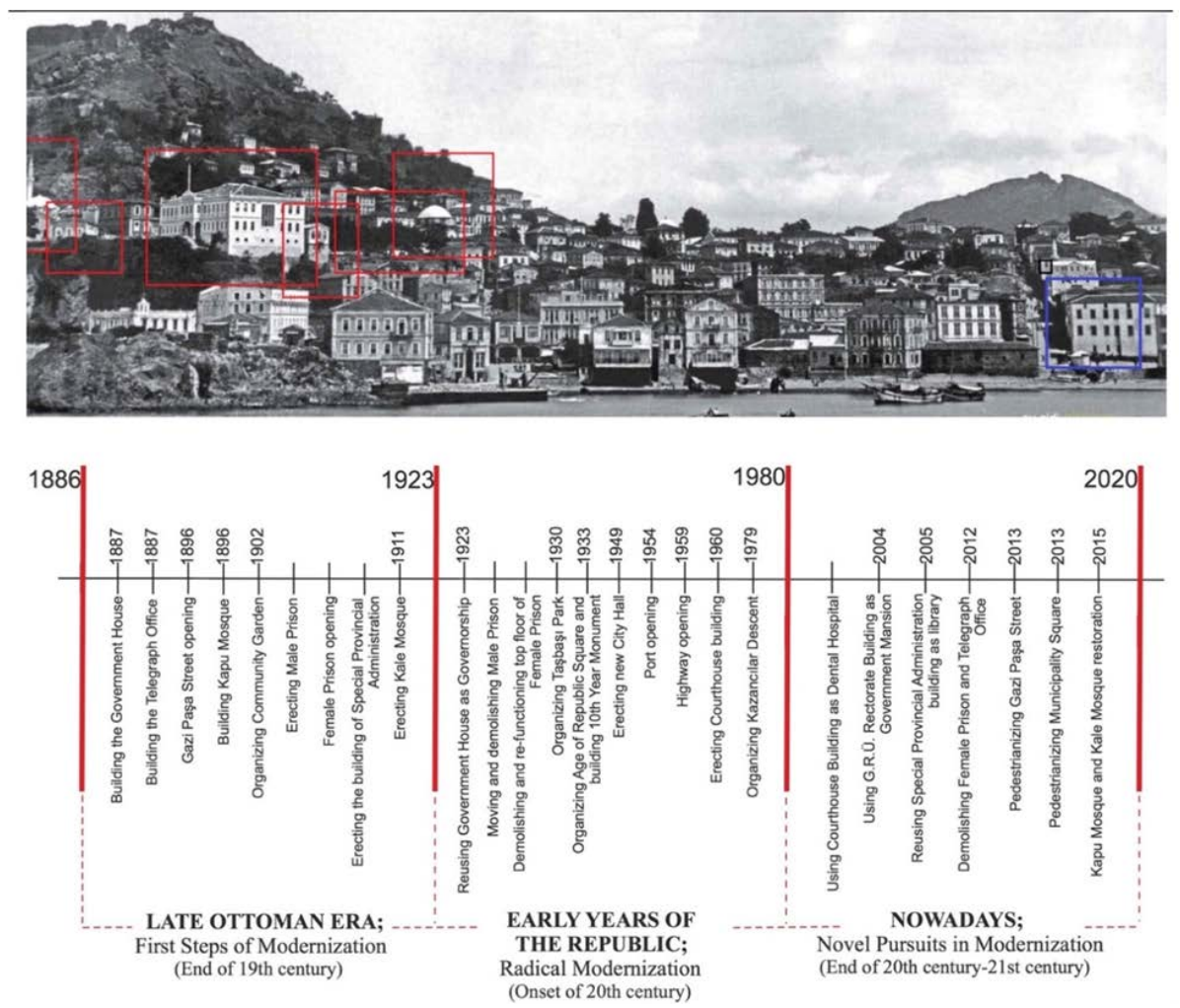

First Steps of Modernization (End of 19th Century): Building Giresun Government House and Administrative Center

In the last quarter of the 19th century, as required by the evolving administrative system, a symbol of the sites where, in accordance with urban topographic structures, the administrative functions were collected is the site known in Giresin as the Government Square . This square that placed the Government House at its center is situated on sloping land and as time passed by, it evolved into an Administrative Center in which the surrounding structures were defined. Thus, the union of the structures within the Administrative Center not only displayed a collective city image, but it also empowered the modernization perception in the city. Within that context, the Government House is the very first structure that defined the Administrative Center, which was topographically situated onto a dominating site of the view over the city and the port. It is also the most powerful architectural image in the square. In due course, next to the construction works in the city, a number of urban and architectural elements that would serve for the modern functions demanded by the period were built. The government square moved beyond a site in which only central administration functioned. Rather it became an influential public site that had power in local city policies. The Community Garden that instilled the square function in the
Figure 2. End of the 19th century, Giresun Government House and Administrative Center Structures (Işık and Dervişoğlu,2011), Construction Processes (Prepared by the authors) 
land before the Government House, the Special Provincial Administration and Male Prison built right opposite the office, the Female Prison right beside the office, Gazi Street that opened towards the government square and offered various trade functions, telegraph office, Kale Mosque as well as the open and closed public space formed by Kapu Mosque collectively transformed the Administrative Center (Figure 3).

Figure 3. First Steps of Modernization (end of 19th century): Building Giresun Government House, Administrative Center and the urban space $^{5}$ (Prepared by the authors)

\footnotetext{
${ }^{5}$ In order to facilitate reading and demonstration, the structures are firstly coded and arranged in a chronological order. In this context, the Government house is defined as (code1), Telegraph Office (code2), Gazi Street (code3), Kapu Mosque (code4), Millet Garden (code 5), Male prison (code 6), Female prison (code 7), Provincial Private Administration (code 8), Taşbaşı Park (code 9), Cumhuriyet Square and the 10th Year Monument (code 10), the New Municipality Building (code 11) and Municipality Square (code 12).
}

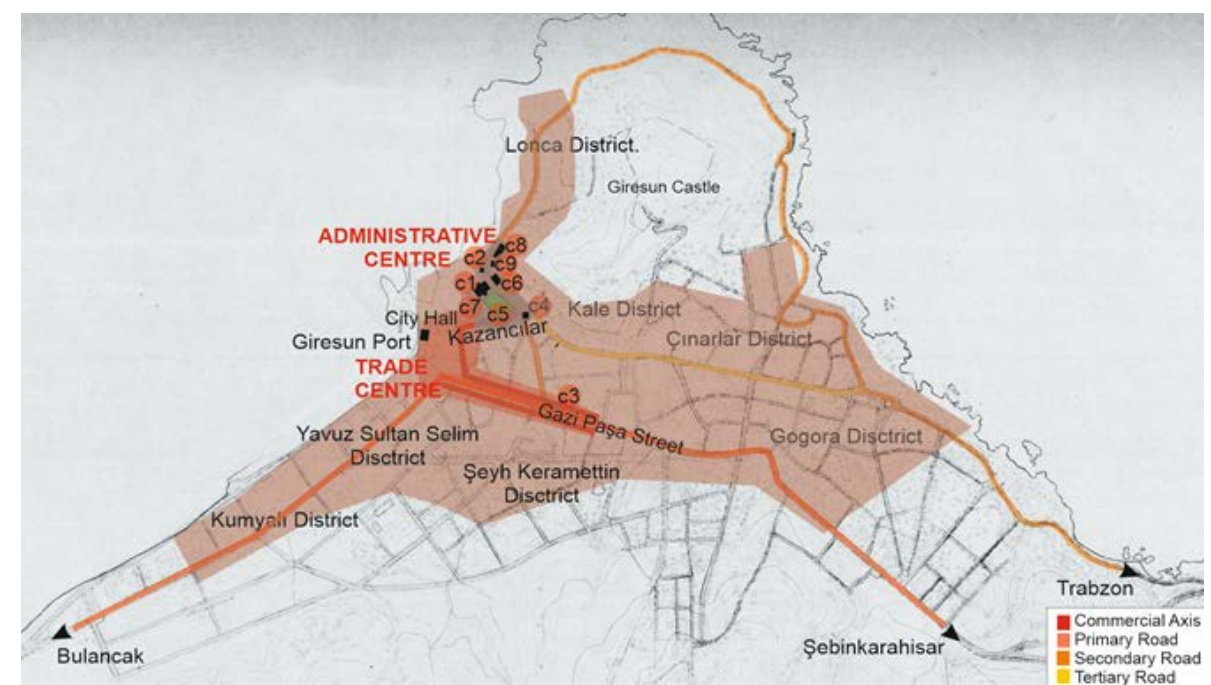

\section{Building of Government House}

The presence of a Government House in the city as of the 1860s has been documented (Balcl, 2012). In the early years, an old mansion situated in a dominating position towards the city while also representing the most magnificent structure in the square was rented to be employed for administrative use. In 1886, after abandoning the idea of functioning old offices in cities as Government House; there a novel Government building was built in the city. The mansion of which construction works first began in 1887 was, as documented in the archive records, had plan and map works in 1886 (Karaman and İltar, 2008); yet its original drawings are yet to be found (Figure 4). It has been stated that it was built by the decree of the Municipality Mayor Captain Yorgi Konstantinidi with the support of District Governor Ziya Pasha that construction expenses for the Government House were reimbursed with the donations of locals (Balcl, 2012). It was positioned on the castle road that connected the city with the Trabzon Province and at the intersection of one of the very first settlements: the Kale District and Kazancllar Descent. Since, in the said period, there was not a coastal road passing through the shoreline, the axle where the mansion was erected stood as the main artery connecting the city with its hinterlands. Right opposite the western gate of the Giresun Castle walls some of which were demolished within historical process (Karaman and İltar, 2008), it was erected in a dominant position both for the port and the city by leaning its back on the feet of the castle. As is common in many provincial towns, no data exists in the official records on the master of the structure and the commissioned architect. 
Yet, considering the masonry structures of the period, it can be argued that they reflect the craftsmanship of Non-Muslim stonemasons.

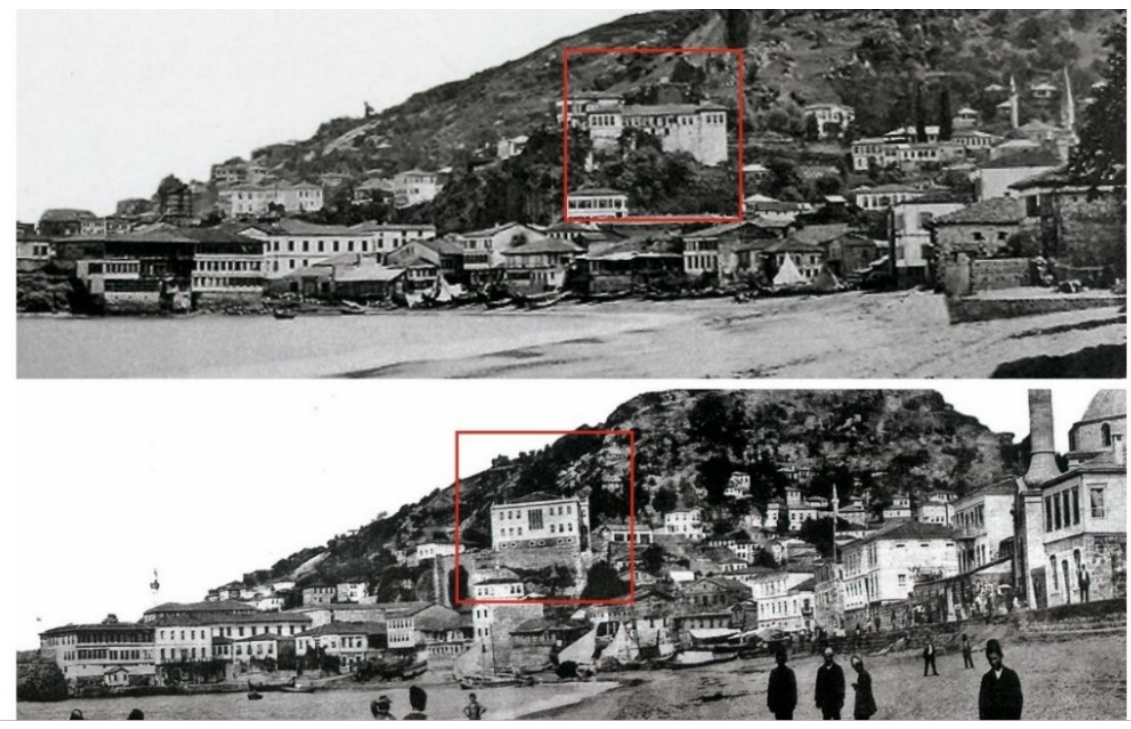

The building is recognized by its duty to represent state reputation, but at the same time, as a symbol of the first steps of modernization in the city, it is the very first structure articulated in the urban fabric of the city. Large enough to meet the spatial needs of an expanding provincial bureaucracy, it enlarged as a symmetrical mass in a rectangular figure and horizontal growth; thus, displaying certain similarities with the specimens in a Neo-Classical style. Due to the topographic traits of its situated land, it is accepted as a masonry building consisting of two floors placed onto a half-basement ground. Two main gates matched to the building through its east-west facades can be provided via penthouses that were highlighted by protruding from groundmass and completed by triangle frontons. As a popular trend in that age, in order to display state symbols, there was the Sultan's tughra and various embroiders mounted onto penthouses. The spatial plan of the building was determined by rooms placed around a wide rectangular interior sofa, two curvilineal stairs placed onto symmetrical axle of the narrow bands in north-south axle of the sofa, and entrance gates placed into the east-west axis. Windows that had relatively wider gaps than the typical public buildings of the age allowed the interior sofa of the structure to receive light and the ability to control the port as well as the castle entrance gate (Figure 5).

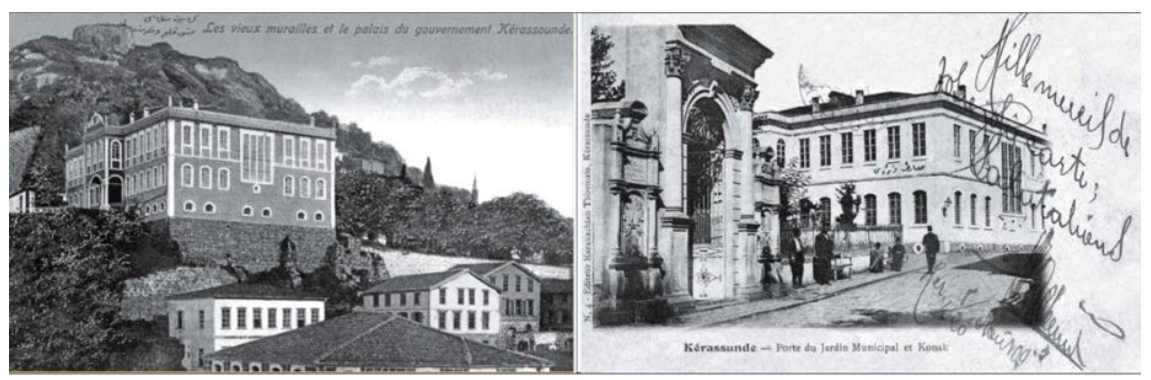

Figure 4. End of the 19th century: The old mansion employed as Government House and newly-built Government House (Işıı and Dervișoğlu, 2011)
Figure 5. Ends of the 19th century, Government House (Istanbul University, Ylldız Records, No: 90854-0027) and Government Square (Işı k and Dervişoğlu, 2011) 
${ }^{6}$ In the "Salname-i Vilayeti Trabzon 1313/1896 p.247" annual, it is stated that "During the rule of the esteemed Mayor Captain Yorgi for a period of 18 years; modern streets were opened in the city, pavements were built, and gardens, parks, fountains, and roads that led to the castle from both ends were erected". As seen, the street referred to here was taken as Gazi Street.

Figure 6,7. End of the 19th century; the former building used as a Telegraph Office, and Gazi Pasha Street (Işık and Dervişoğlu, 2011)
A Review of Modernization: The Giresun Government House and Administrative Center

\section{Building of Telegraph Office}

The new administrative system envisioned by modernization mandated to build telegraph offices that would assist central administration in controlling the province, and an example of such structures was erected in Giresun. It has been reported due to the telegraph line installed in 1869 from Trabzon, the building in the city of a telegraph office was discussed (Karaman, 1999). Resources also mention that in different periods there used to be two telegraph office structures situated in different regions of the city. The very first telegraph office structure in the city was the edifice right next to the Government House which was reported to have been demolished in 1871 (Mercan, 2009) (Figure 6). In due course, the need for a secondary structure became apparent. The construction license for the secondary telegraph office positioned in the İskelebaşı location was issued in 1887. There was damage in the building due to the 1907-dated fire in the square (Mercan, 2009). Thus, in line with the functional meaning of secondary structure, despite not being built right inside the Administrative Center, positioning in a site connected with the municipality and port could still help to secure central supervision, which can be thought to add value to the Administrative Center, though indirectly.

\section{Restoration of Gazi Street}

The former trade axle, also known as Kazancilar Descent represented a traditional trade center where artisans were mostly situated: Gazi Street on the other hand, symbolized a novel trade axle in which new commercial functions such as draperies, pharmacies, and Western style chic department stores and restaurants were located (Figure 7). In the ensuing years of the Government House construction, the streets were furnished in cobblestone pavements ${ }^{6}$ and provided new spaces to open places that could meet emergent functional necessities. In that sense it can be argued that as the very first open public space of the modernization process in the city, it offered an early practice for modern life, and symbolized the modern trade center in the city. By the east-west axle additions to Gazi Street that determined the transportation network character of the city, access to the Administrative Center became more convenient and they also acted as a backbone in providing a spatial representation.

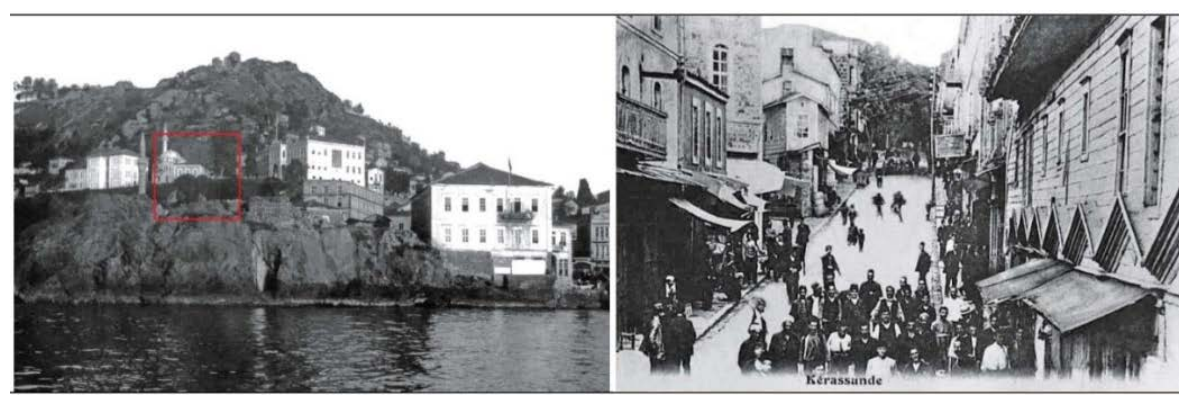




\section{Kapu Mosque and 1911. Rebuilding of Kale Mosque}

Although during this period, the aim was to create a modern city image through public buildings, religious structures that were erected in line with the novel architectural trends of the period can be categorized as the structures depicting the administrative centers in provincial towns. In the same vein, the Kapu Mosque (1896) that was already present in the Giresun Government Square (Figure 8) and Kale Mosque (1911-12) were demolished for construction works in the reign of Abdülhamit II and were then rebuilt (Fatsa and Saritaş, 2012). That being stated, it can be claimed that both mosques formed a partnership by means of their spatial connection formed with the Government House and with the ideology of the age thanks to their architectural styles. On the other hand, after their reconstruction, these mosques contributed to the frequency of using the Administrative Center and offered a spatial continuum as the components of this Administrative Center.

\section{Building of the Community Garden}

The community gardens that were organized as a micro model of Western parks were situated either right opposite the Government House or in land dominant to the city. Situated right next to the Giresun Government House, the Community Garden was built in 1902 as an outcome of a similar perspective (Figure 9). Its interior space decorated with a myriad of trees of different kinds, offered the citizens novel forms of recreation. It could be accessed through a wide and vaulted monumental crown gate, and both sides of the crown gate exhibit fountains that were situated in a symmetrical organization. In those years, the incompatibility between the daily life practices of Muslim residents and modern life practices provided in the park resulted in the recognition and using of this site by only a limited segment of community for a certain length of time. Nonetheless, in the narrations of Osman Fikret Topallı (Usta and Çulfaz, 2017), this perception evolved in due course, and the park turned into a center where many intellectuals convened and talked about current affairs.

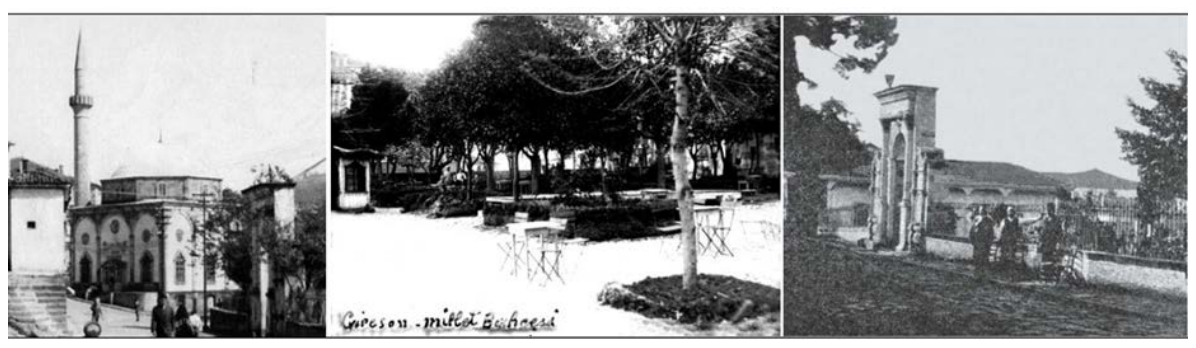

\section{2-1911. Building of Men's and Women's Prisons}

Until the end of the 19th century, lodges, military posts, jerry-built structures or office basements were used as prisons in a vast majority of Ottoman Empire provinces. However configurations made on crime law as an effect of modernization increased the spatial need for prisons
Figure 8,9. End of the 19th century; Kapu Mosque (O. Öztürk Archive), Community Garden and its door (Işılk and Dervişoğlu, 2011) 
(Sunay, 2018). Ancient photographs and verbal stories of the city prove that the structure that was erected right beside the mansion after the construction date of the Government House and replicating identical traits to the prisons in the specific age, belonged to the female prison (Figure 10). In the same vein as evidenced by the ancient photographs and verbal stories of the city structure, having a rectangular massed, framed window, a spectacular gate, which was erected right opposite the Government House and belonged to the Male Prison (Figure 11). Nonetheless, as seen in Giresun, prisons have always been a symbol for the central sanction power of the governor appointed from the central state and for an extensive amount of years, have become indispensable elements of spatial context by tightening a functional union with the city's Government House.

Figure 10,11,12. End of the 19 th century; female prison, male prison and the Special Provincial Administration (Işılk, Dervişoğlu, 2011)

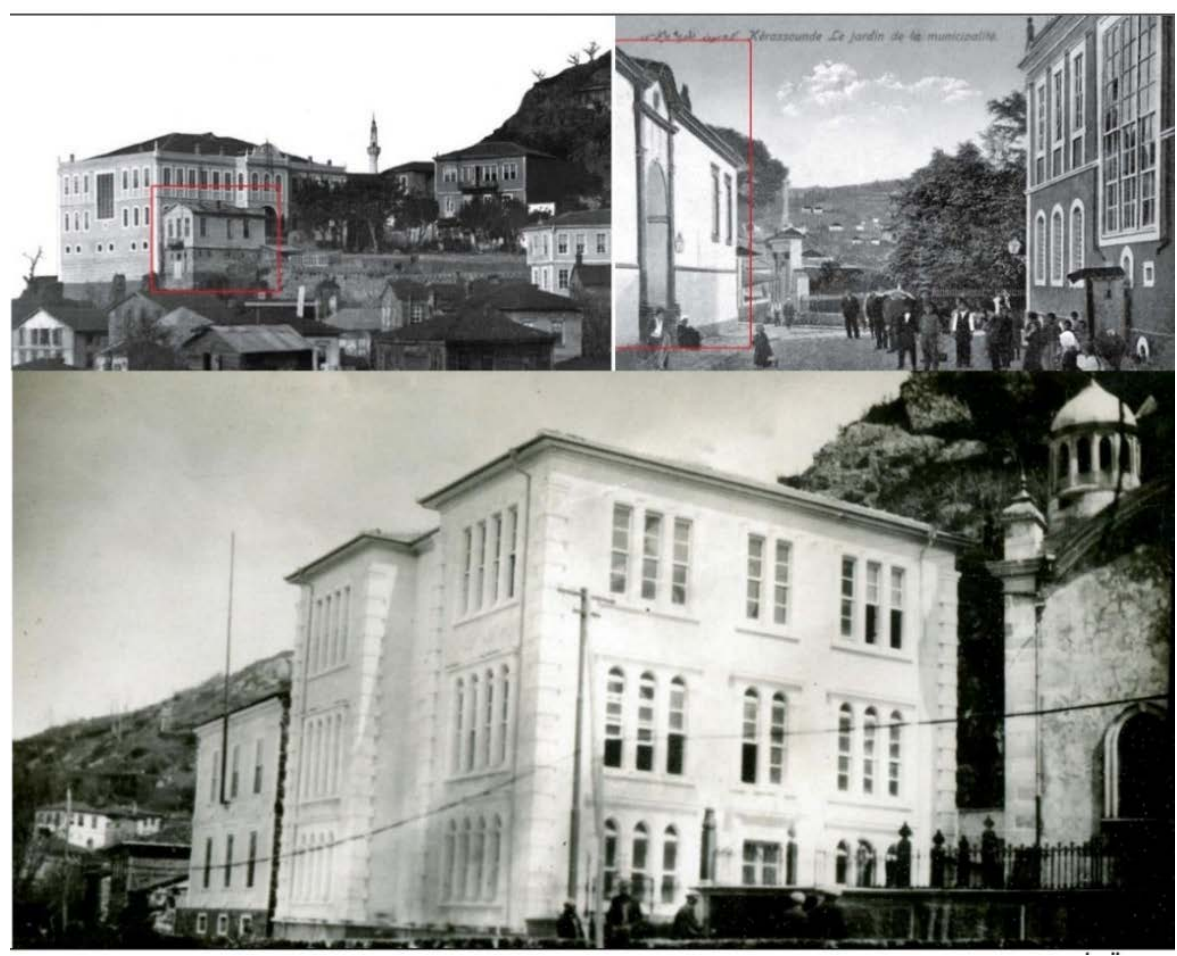

1902-1911. Construction of Provincial Private Administration

There is no conclusive data on the construction of the Giresun Special Provincial Administration which came to life as an effect of the administrative changes implemented in the provincial towns after the 1864 Province Code of Practice. Yet, photograph archives evidence that the building was constructed following the completion of the Community Garden. The Special Provincial Administration on the main axle that passes in front of the Government House and enables the city's connection with the east was positioned as one of the components of the Administrative Center (Figure 12). In respect to both building material and architectural traits, the structure bears the general architectural trends of the period. These construction works that started with the Government House and ended with Special Provincial Administration 
elevated both the local and central public quality of the region. While a few structures were positioned in a figure to surround the square, some others were situated in a linear axle connected with the square. The unity they had empowered the authority of the center and also gave impetus to the housing structuring in its vicinity. Nevertheless, the housing structures were essentially modeled on a residence with a garden and targeted people with a high income-level.

\section{Radical Modernization: Early Years of the Republic (onset of the 20th century): Past Times of the Giresun Government House and Administrative Center}

Upon the proclamation of the Republic, further steps were taken to rehabilitate the physical conditions in the war-stricken Anatolian cities, and add to the urban space the kind of architectural structures that could meet the functional necessities of the novel administrative organization envisaged by the Age of the Republic. Such spatial transformation and construction works that were partially transferred from the Ottoman Era to the Age of the Republic manifested an even more radical approach within the axis of Republican ideology. During this process, there was need for novel structures that could meet the demands born out of administrative and social changes emergent in Giresun, which had recently gained city status. Here, novel practices also took place. In that case, through Giresun, one can witness the radical modernization practices which transformed the Anatolian cities in the first years of the Republic.

A replicate of the master plans that were prepared in the 1930s to ensure a planned growth for Anatolian cities was also concocted for Giresun. These plans that differed from each other due to the unique local and topographic traits of the cities possess the same outline in principle. Yet, the Giresun master plan, a.k.a. 1933 plan (Anonymous, 1933) lacked any conclusive decisions that directed the urban growth axis, except for the micro interventions that could contribute to the growth of urban space. On the other hand, in the time interval from 1923 to 1937, the Giresun municipality that employed pier revenues to fund municipalism works experienced resource shortages after transferring the pier to Denizbank; therefore, the construction work almost came to a halt (Kabacaoğlu and Dervişoğlu, 2019). Thus, in the time period between 1937-1946, it can be claimed that the city had failed to have a holistic modernization experience, but still a number of actions such as opening orderly roads, squares, wide green zones, city lightening, and forming a regular transportation system were achieved. After 1946, the enlarging of the capacity of the pier and retransferring the revenues to the municipality accelerated the construction work in the city. Several public buildings were erected in the city to serve different functions. In the 1950s, the improvement in economic indicators started a phase when architectural structures that would meet the emergent functions of the new organization and derived their creative powers from the conceptual 
depth offered by modernization, were articulated into the urban space. This city which, until the 1960s, experienced an insignificant population growth and used current housing stock went into a rapid growth process after this date. Factory sites were disjointed from the urban space, and the Micro Industry Site was built, the Forestry Management was built, and the novel housing sites were opened in Gemilerçekeği and Teyyaredüzü, and significant decisions were taken to stop squatting in the vicinity of Fiskobirlik. In 1976, a model of the Seka-Kağıt factories built within the scope of the first five-year development plan was constructed in the city. In 1979, when Fiskobirlik became a business engaged in industrial production and the Entegre campus which was then built, played a role in urban growth.

Thus, urban growth that had been limited to the north-south axle, now moved towards the east-west axle paralleled to the shore. In other words, it moved towards the Seka-Fiskobirlik connection. In that case, a slowpaced growth monitored until the 1950s, gave impetus to the building of a port and highway, which directed both the physical and economic growth of the city. During this process, when the new public buildings, which identified the urban silhouette, were articulated into urban space, the Administrative Center was integrated with a central business facility that reached to the port and the highway. Nevertheless, in this process, despite the shift of axis in the growth trend of the city as well as radical functional changes and demolishment seen in the entailed structures, the Administrative Center preserved its bureaucratic and management center identity through which the unity of the surrounding structures could be validated (Figure 13).

Figure 13. The onset of the 20th century: Administrative Center and urban space (Prepared by the authors)

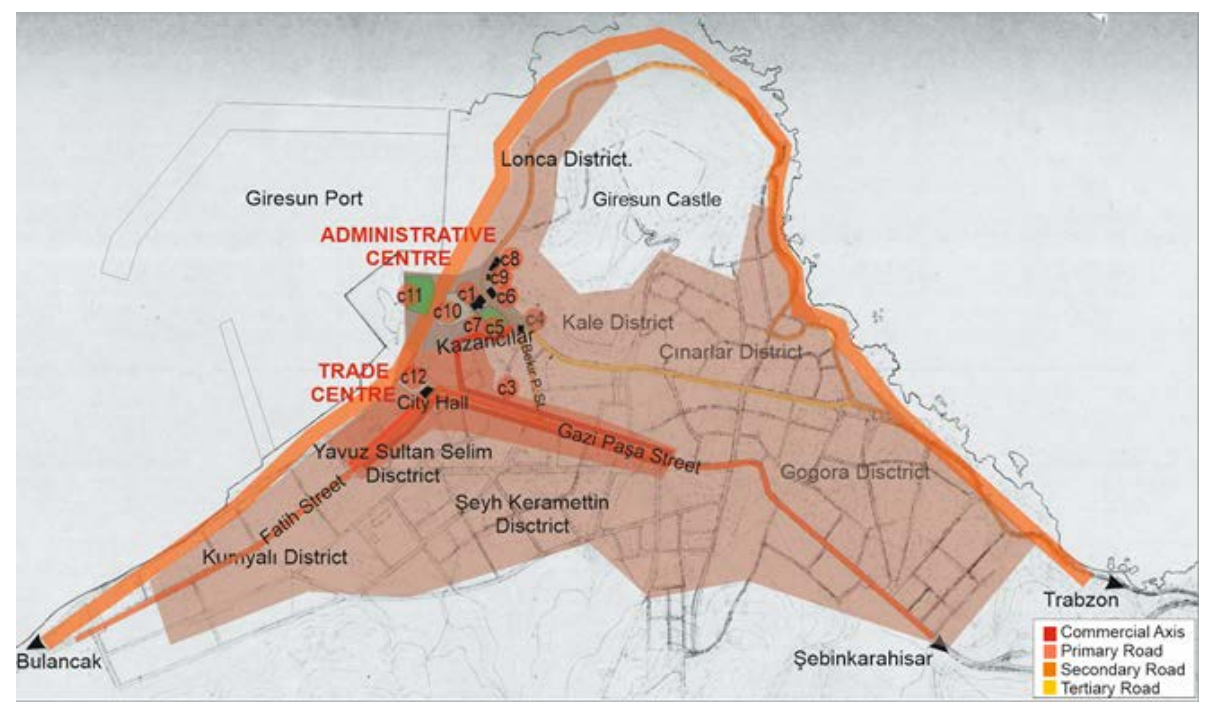

In this process, Government House was used as the Governorship Building; thus, continuing its power and influence at the Administrative Center (Figure 14). In this building, very limited renovation work was conducted in the sense of architecture, and any generic change was avoided. The most noticeable intervention on the structure can be 
observed in its tughra and epitaph sign. It is suggested that in these interventions, the 1927-dated law ${ }^{7}$, played a role in removing the tughra and praises that were symbolic marks of the political rule in the Ottoman Era and in the dyeing of epitaphs. Gazi Street on the other hand, continued its growth by attempts aiming not to cause a drastic change in the macroform of the city, but rather attempting to renovate the alreadyexisting work. By opening secondary streets such as Fatih Street, and Bekir Pasha towards Gazi Street, a central business facility in which trade operations took place, empowered its identity. In Gazi Street, the most generic restoration took place in parallel with the increased number of urban traffic in the 1960s (Işık Newspaper, 1960) and as of the last quarter of 19th century, Gazi Street was opened to vehicle traffic. Hence, as of 1923, a linear connection that the city gradually built on the northsouth axle became much more powerful, and accessibility to different points in the city rose. Such practices that turned a community garden into one of the attraction points of the inner-city pedestrian movement, also supported the definition of a park as one component of modern public life. It is attested that during these practices, the Community Garden gate that was in the center of the roadway was pulled one meter backwards and moved into its current position (Yeşilgiresun Newspaper, 1930). Local newspapers narrated these practices in the period as; 'The Blooming Garden' (Yeşilgiresun Newspaper, 19 June 1930). Still, these modernization practices performed in the Government House, focused Administrative Center, signed off the Male Prison and Female Prison due to spatial shortage in the region. Initially, the Male Prison was moved to the Metamorphosis Church. Later, the Female Prison that was almost positioned adjacent to the Government House was demolished; except for the basement floor to be used as an achieve room in the future.

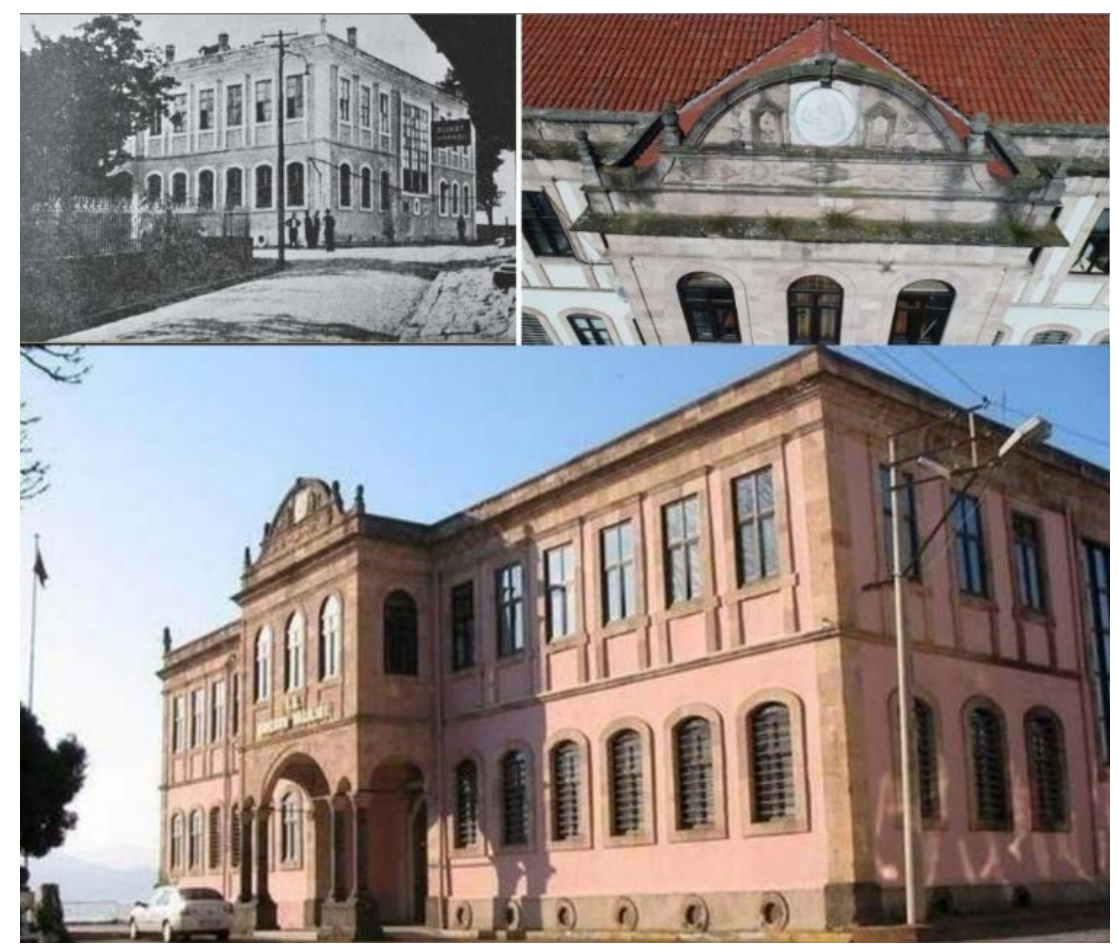

7 For detailed information see (Umar, 1981).
Figure 14. 1930s, Government House and damaged tughra (Mehmet Fatsa Archive) 
Figure 15. 1930s, The building of Taşbaşı Park (H. Menteșeoğlu Archive)
A Review of Modernization: The Giresun Government House and Administrative Center

\section{Construction of Taşbaşı Park}

Taşbaşı Park built by the seashore in the İskelebaşı location in the south of the Government House was a manifestation of this approach in Giresun (Figure 15). In this park, situated in an above-sea level, spatial organization manifested a preference for geometric forms. Access to the park was possible through the stairs in the symmetrical axle of the 10th Year Monument. Via this space, it became a frequent point of visit in the city for many years. Yet, after the construction of the 10th Year Monument and Republican Square, the site where Taşbaşı Park was also present, became an open public site that symbolized the ideology of the Republic; hence, empowering its semantic existence also. The evolution of the visual association formed with Government House into a functional connection through the Kazanclar Descent, contributed to the unity formed with the Administrative Center. However, transiting the highway from the shoreline in the 1950s reduced Taşbaşı Park's connection with the Administrative Center, the Republican Square and the City Hall to the rank of a visual perception only.

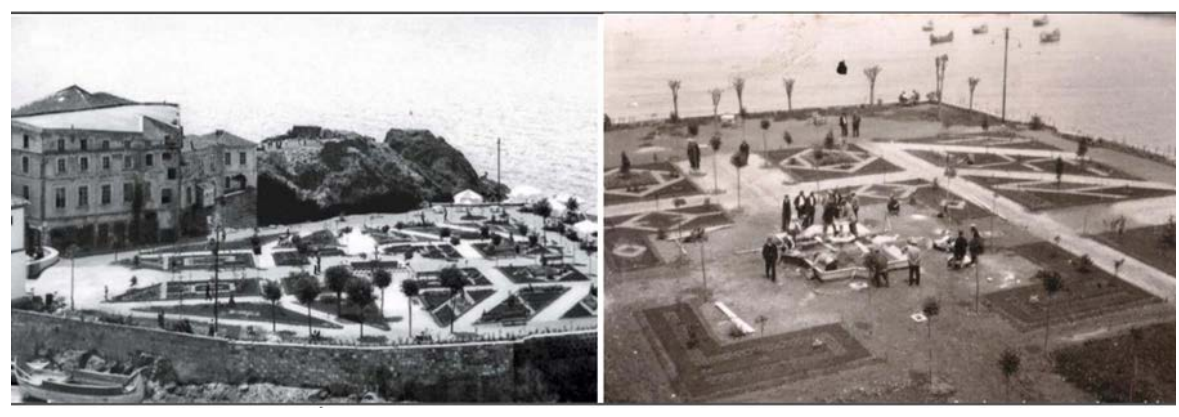

\section{Construction of the Republican Square and 10th Year Monument}

As a symbol of Republican ideology in urban space, this monument was constructed in 1933 right before the Government House, and in topographic criteria, it was built in its bottom elevation. In its age, this monument empowered the Administrative Center function of the region. Naming the site before the 10th Year Monument as the Republican Square, it was vital it be organized in a way to perform official ceremonies and celebrations. That was because the location of the Proclamation of Republic celebrations was moved from the Government Square to the Republican Square; thus, the community identity of this place heightened. Although this was not an open urban site determined by its surrounding structures and depicted within the framework of geometrical rules, it still had a square identity by means of its functional meaning, position, and scale (Figure 16). 


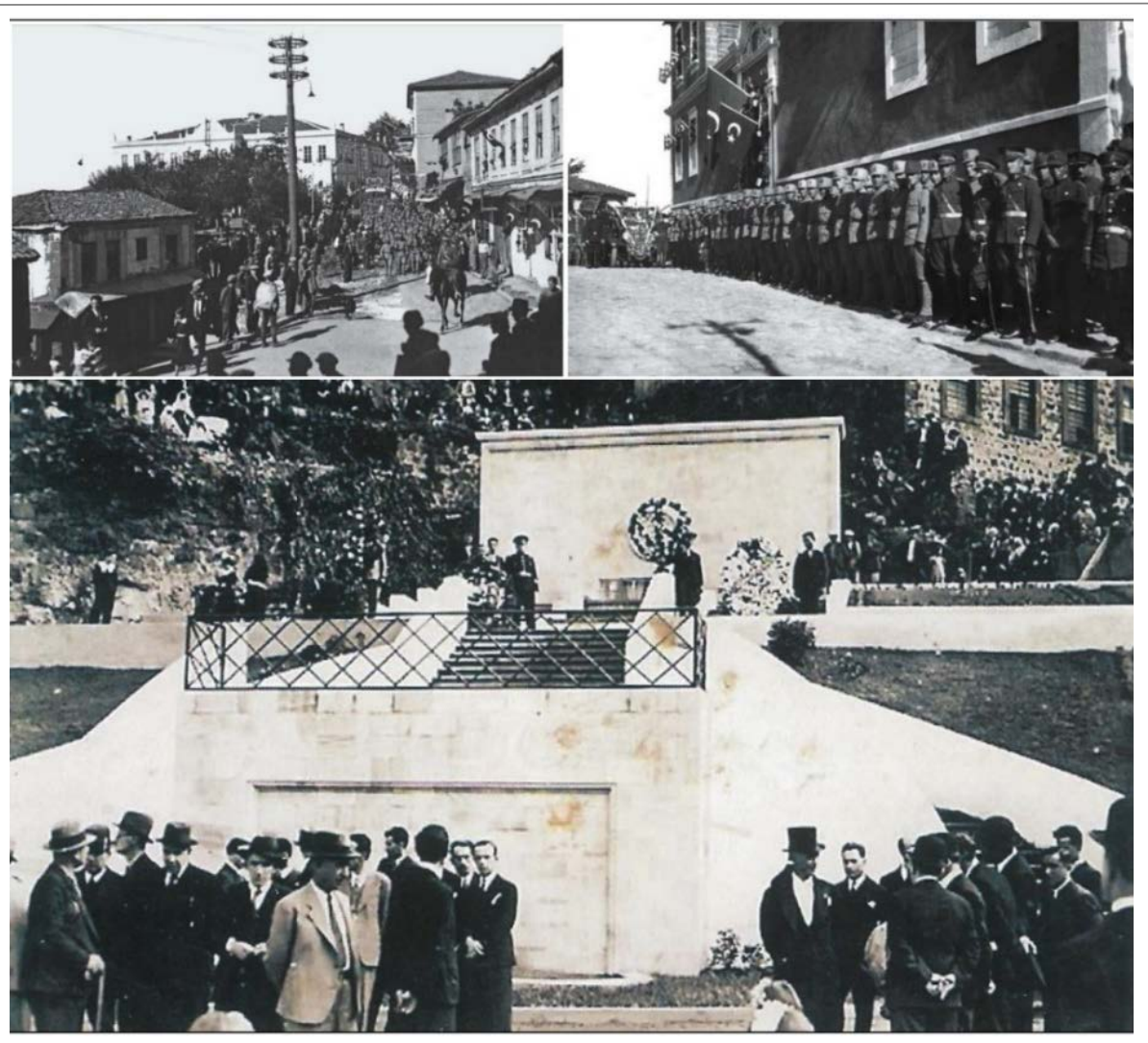

1949. Construction of Giresun City Hall and 1960. Restoration of the Square

Giresun City Hall was erected in place of the former city hall demolished after damage in 1939 from the Erzincan earthquake (Anonymous, 1973) and conducted organizations that used the site before the structure and identity of the square, could elevate the city-center character of the region. As a result of this change, the usage density in the Government House focused Administrative Center went down, and in the modernization perception, a change of perception towards a Municipality-Square focused axle took place (Figure 17). With the spatial plan and mass formation the building had, it became one of the most noticeable models of the modern architecture perspective in the period. Located at the focus point of the city center in the very first years it was built, the structure connected the Republican Square where official ceremonies were held on Osman Ağa Street. In 1969, with an aim to remove the worn-out and soulless structures that confined the Giresun City Hall and its front site, confiscation work commenced in the parcel between the City Hall-Hacı Miktad Mosque (Yeşilgiresun, 5 Sept. 1969). Such practices that would highlight the City Hall in the city silhouette, also restricted the growth of the Administrative Center; hence, opened the road for the construction work that would culminate in a loss of value for the Administrative Center.
Figure 16. 1930s, Republican Celebrations in Government Square and the Opening Ceremony of the Monument of the Republic (Kabacaoğlu Archive) 
Figure 17. 1950s, City Hall and 1960s, Municipality Square (Kabacaoğlu Archive)
A Review of Modernization: The Giresun Government House and Administrative Center

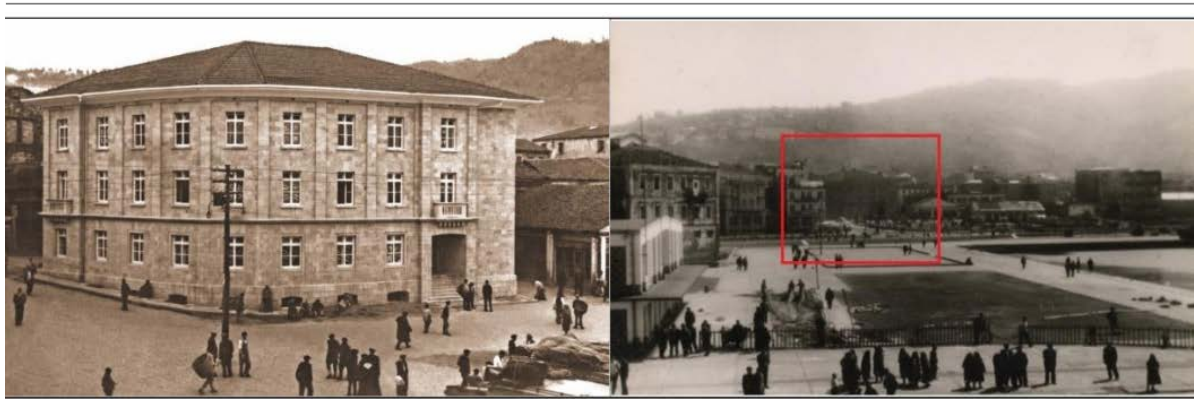

1954. Port and 1959. Construction of the highway

After building an extensive and equipped port, the opening of the Black Sea coastal road to service was among the practices that increased the ate of urban growth within this period (Bekdemir, 2015). The highway opening limited the connection between the city and the sea, but by erecting the port, there was a noticeable speed in the overseas trade expansion of the city. It can be argued that the building of the highway and the port, severed the physical tie between the Administrative CenterTaşbaşı Park and put limits on the growth of the Administrative Center. The roads passing though the Administrative Center began to be used as an inner-city road, which in effect significantly affected the density of usage in the region.

\section{Construction of the courthouse}

In the 1960s, it was built right opposite the Government House in place of the Male Prison. With its wide eaves and rectangular mass expanding horizontally, it possessed a uniform and plain facade look. Its monotonous facade organization created by the windows that formed an orderly range, was disrupted by the cubic dent where the entrance was accentuated. In that sense, it displays a modern architectural system. In its construction, cut-stone andesite excavated from the Giresun Bıçakçı village was employed (İltar, 2014). In terms of modern architectural language, it had found existence through a different and novel expression within the generic fabric of the city; thereby, embodying the ideology of the Age of the Republic within the city. By erecting a Courthouse in place of the demolished Male Prison, a spatial unity between the administrative and judicial body was established.

\section{Organizing Kazancılar Descent}

Searching for an alternative route to the ends of lessening the traffic load on Gazi Street gave rise to road expansion work in a way to encompass the Kazancilar Descent. However, its physical and spatial deficiencies and the demolishment of many of its commercial structures while conducting construction work, changed the generic architectural character of the Kazanclar Descent. The stairs that had long been present in the traditional nature of the Descent were destructed in this period. The community Garden was shrunk in a spatial sense and the highway facade of the park was supported by walls. Such practices that opened the coast 
connection of the Administrative Center to vehicle traffic, put limits on the existing pedestrian connection; thereby, diminishing the intensity of pedestrian movement in the Administrative Center.

\section{Changes in the Modernization Perception (The End of the 20th century- 21st century): Current View of the Giresun Government House and Administrative Center}

During the process from 1980 to the present date, some of the public buildings defining the Administrative Center have either been refunctioned or demolished and replaced with new structures. Among the primary reasons that Administrative Center lose its purposeful identity is changing the function of the structure used as the Governorship, the Courthouse Building, and the Special Provincial Administration; demolishing the Female Prison and the Telegraph Office Structures. Therefore, the current status of the Government House focused Administrative Center structures was analyzed through a holistic approach based on the function, location, and architectural traits of the said structures. From that point of view, in the 1980s and later, a determinant factor in the development of cities has been the opening of new housing sites. Alman Çeşmesi, Gemilerçekeği, Teyyaredüzü, and the subsequent Osmaniye and Eriklimanı are some of these settlement sites. In the aftermath of 1980 construction works in the city mainly focused on housing, and the needs unique to the city created a number of differences in the modernization perception. As a result of the increased diversity of the administrative units under the body of the Governorship, the Government House, which was utilized as the Governorship, also became insufficient in terms of a spatial context.

A project competition was organized for this building to be erected as the New Giresun Government House, and the winner of the project in the competition was the work prepared by Architect Semra Özcan Uygur. All of the units in the Administrative Center were transferred to the new building of which construction was completed in 2004, and the Government House was changed to the Karadeniz Technical University. In 2007, it used by the Giresun University Rectorate Building (Figure 18). This change signals the last step of the bureaucratic and administrative function of the Government House focused Administrative Center. 
Figure 18. Present day, Government Square, Government House (Mehmet Fatsa Archive) and Interior Space (Prepared by the authors)

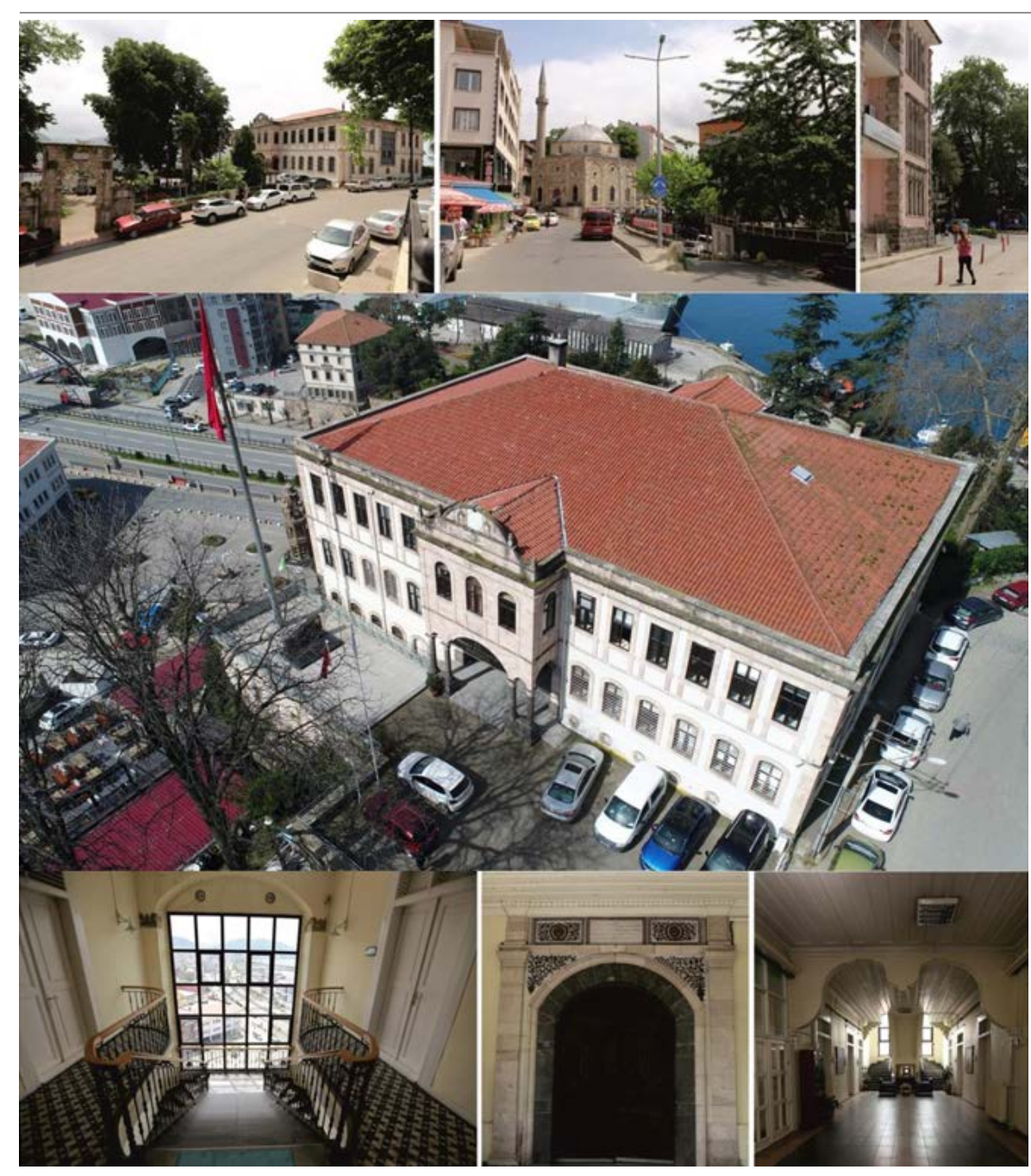

451
The Courthouse and Special Provincial Administration buildings that were moved to the new Government House in 2004 began to be used to meet different functions in this process. The Courthouse Building was, at the beginning, used as Dental Hospital and subsequently as the Supreme Election Board. The Special Provincial Administration on the other hand, started to function as a library in 2005 after the comprehensive renovation it went through, and in memory of the 125 th anniversary of the birth date of Atatürk, it offered service as the 125. Anniversary Public Library (Iltar, 2014). Currently, it offers service as the Provincial Directorate of Culture and Tourism. On the other hand, the Telegraph office structure located on the castle route was demolished during the castle-route expansion work in 2012, and its land was then used as a city observation point (Figure 19). 


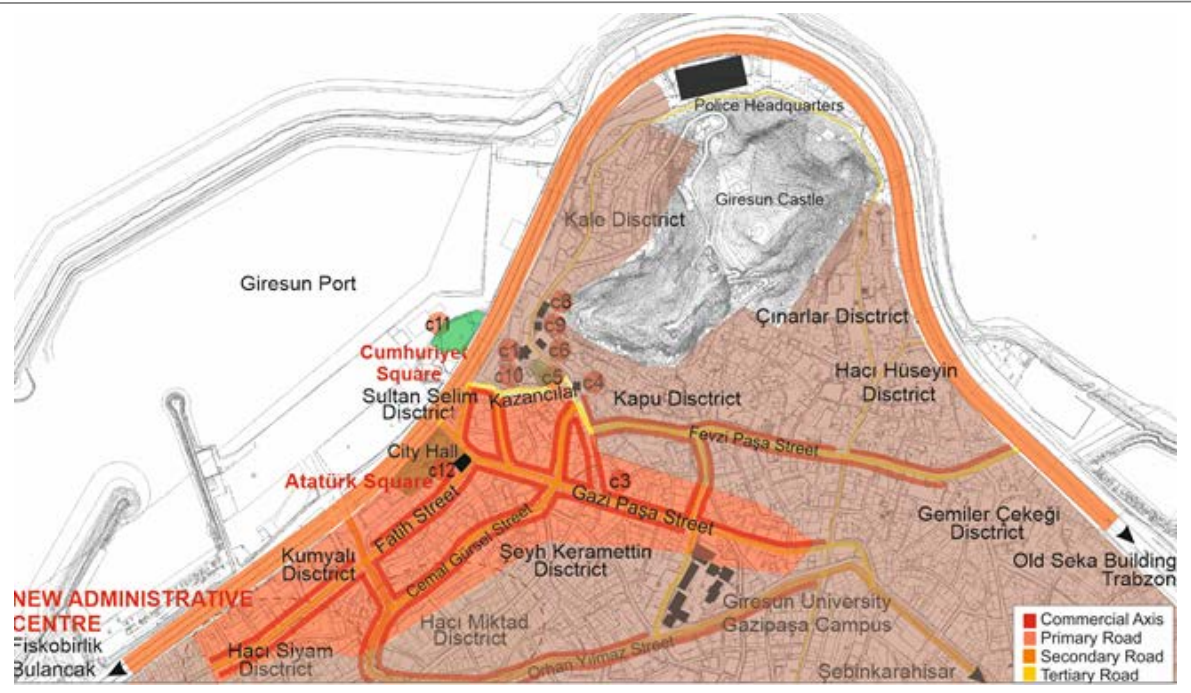

One of the most significant public sites of the Administrative Center, the Community Garden, is among the popular meeting spots of the city even today. Despite the unattended landscape and fitting equipment, and unsupervised additions, it is one of the symbolic icons of city identity. Gazi Street on the other hand, by securing the Administrative Center's connection with the trade center from the Ottoman Era until the Age of Republic, managed to protect the function of the city as the main transportation axle for many years. Pedestrianization work conducted in 2013 heightened its density of usage as the main trade axle. As the religious structures defining the Administrative Center, the Kapu Mosque and Kale Mosque, managed to preserve their spatial and functional values after the restorations (2015) they had undergone (Figure 20).

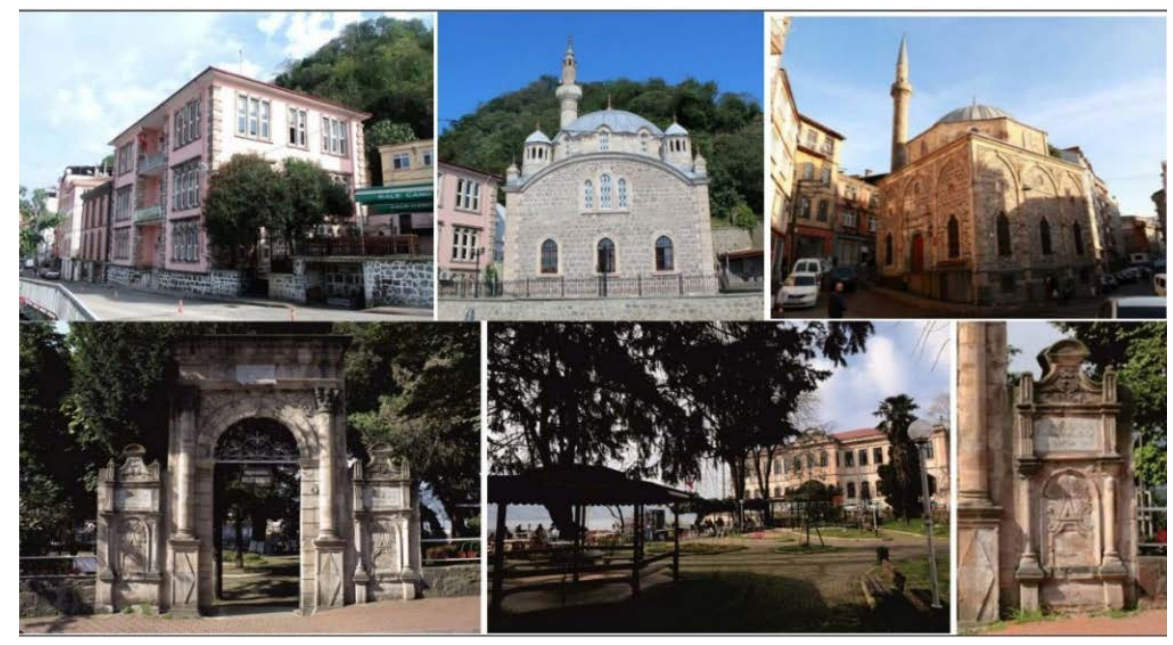

Built in the Age of the Republic, Giresun City Hall used to influence the growth of the Administrative Center has drawn attention as one of the few city halls in Anatolia by virtue of functioning in the same way since the Early Age of the Republic to the present date. In this process, the pedestrianization work conducted in its neighborhood and the organizing of the square empowered its symbolic meaning as a structure
Figure 19. The end of the 20th century- 21st century: Current view of the Administrative Center and urban space (Authors' Archive)

Figure 20. Present day; Special Provincial Administration Building, Kapu Mosque, Kale Mosque, and Community Garden (Authors' Archive) 
Figure 21. Present day; City Hall and Square, Republican Square and 10th Year Monument (Authors' Archive)
A Review of Modernization: The Giresun Government House and Administrative Center

representing local administration. The Republican Square and 10th year Monument continue their existence even today (Figure 21).

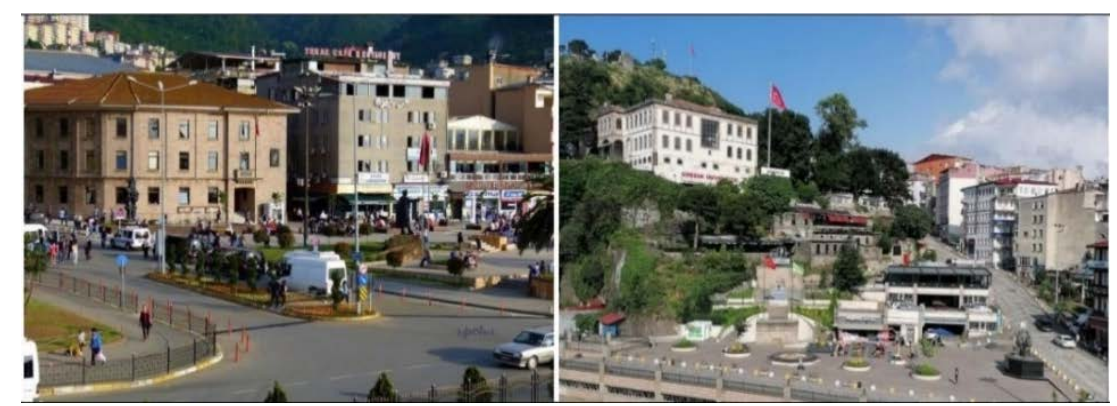

Nevertheless, new formations conducted in the square used as the Keşap Stop have recently created losses in the character and symbolic values of the square as a result of recent food-drink units, shopping departments, and a car-park added to the square. Although in the site, an increased usage density was observed, these additions also altered the visual character of the Administrative Center and created a significant amount of identity loss in this region.

\section{FINDINGS}

In this study the Administrative Center formed around the Government House and its vicinity has been presented as the most important agent of modernization in the province. Evaluating the construction, function change, or demolition of these buildings on the same plane will enable the traces of the modernization experience of the city from the Late Ottoman Era to today to be interpreted and compared. On the other hand, the interventions that were applied to these buildings both during the construction process and afterwards brought about a series of urban and architectural changes, and were effective in determining the city's administrative and commercial center or urban macroform. Within scope of this perspective, the findings of the study are presented through both the changes resulting from the construction processes, function changes or demolition of the Government House and the public buildings that define the administrative center established at the center of the Government House and the directive effect of this change in the trade center and improvement of the whole city.

\section{Change of the Administrative Center and the Structures Defining the Administrative Center}

The administrative center of the city on the Trabzon road in the Late Ottoman Era is located at the intersection point of the Kale and Lonca District, at a point that dominates the city, but has a limited spread due to the topographic characteristics of the city. In this sense, the structures constructed as the buildings of the administrative center are the Government House, Community Garden, Gazi Street, Telegraph Office, Women's and Men's Prison, Special Provincial Administration, Kapu 
Mosque, and Kale Mosque. Some of these structures are located in a way of surrounding the government square and some are on linear axes connected to the square and are positioned with each other in a functional and spatial or visual relationality. In the first years of the Republic, use of the Government House as the Governor's Office, the partial demolition of the Telegraph Office, the complete demolition of the Men's Prison, the continuing use of the Community Garden, Gazi Street, Kapu and Kale Mosque for construction purposes ensured the continuity of the administrative function of the administrative center. However, the construction of a new municipality building in place of the existing municipality building and the creation of a square in front of this building and the connection of this square with Taşbaşı Park, the Republican Square and the 10th Year Monument, which was built just below the Government House at the same time, directed the development of the administrative center towards the coast. It can be said that the construction of the highway and the harbor had a limiting effect on this development. In the 1980s and later, the Community Garden, Gazi Street, and the Kapu and Kale Mosque preserved their functions as the structures of the administrative center, and the Government House was transformed into the Rectorate Building, and the Private Provincial Administration into a library. The Telegraph Office and the Women's Prison were demolished (Figure 22).

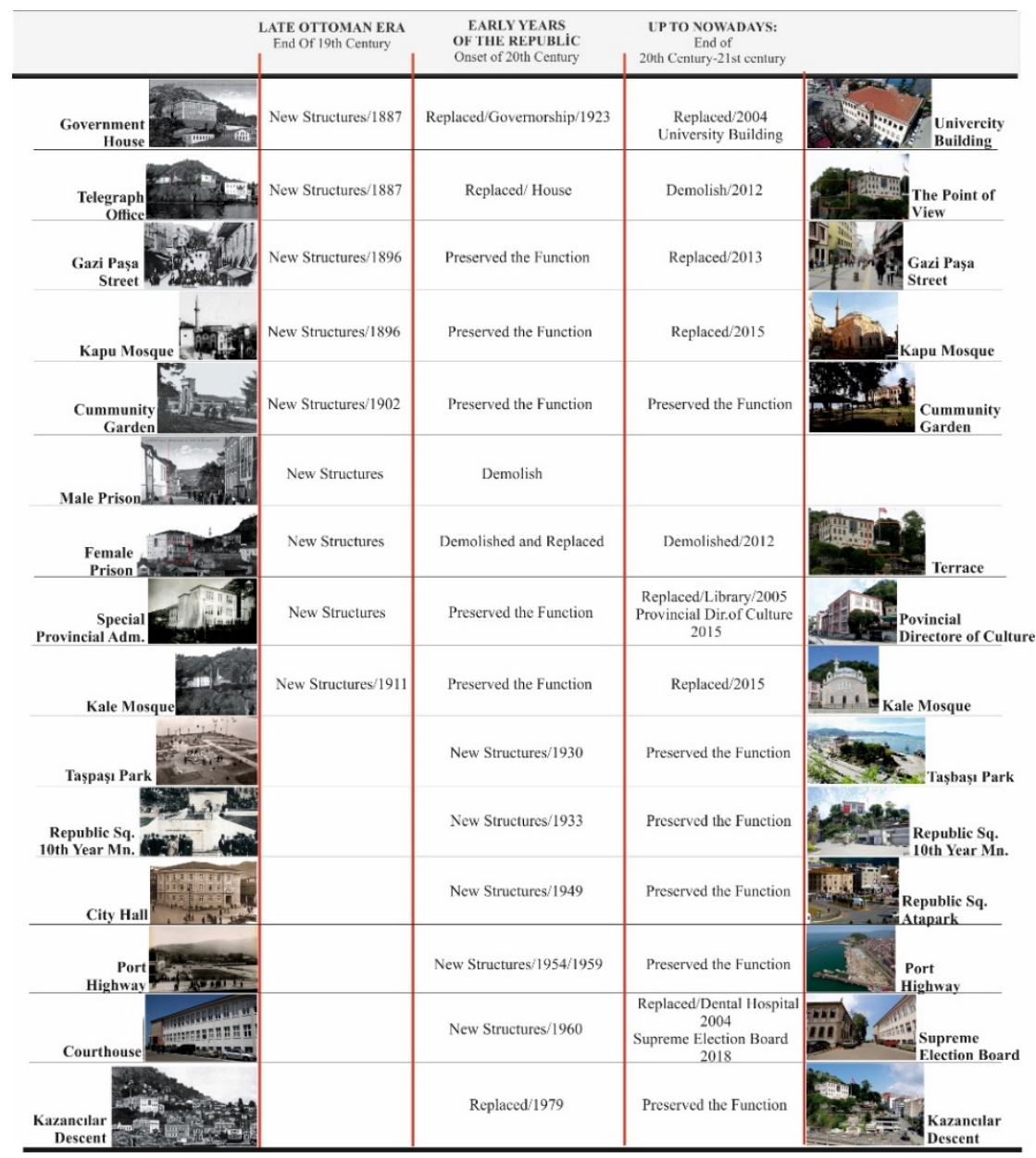

Figure 22. The process of building, function change, or demolition of the structures that define the administrative center (Prepared by the authors) 
The use of the Government House as the Rectorate building during all these developments and the following period, caused the region to lose its administrative characteristics completely.

\section{The Effect of Change of Administrative Center on Urban Space}

In the late Ottoman period, the commercial center of the city was defined by the Kazancllar Slope, where traditional chamber relations were carried out, and Gazi Street as the new trade axis. Over time, the importance of Gazi Street increased with the commercial activity of the city and was supported by new buildings lined up with modern functions. The commercial center development was directed from the Kazanclar Slope to Gazi Street, which connects to the port and sea, and continued its development on the north-south axis (Figure 23). In the first years of the Republic, the Greek Mavriki Mihalaki mansion, which is located on the connection axis of Gazi Street with the sea, was used as the municipality building, strengthening the commercial effect of the street, which facilitates the access to commercial mobility around the port. The demolition of this building and the construction of a new and modern municipality building in its place and thus, added to the urban space after Taşbaşı Park, Cumhuriyet Square and the 10th Year Monument strengthened this effect. However, the construction of the harbor and the highway in the 1950s limited the strong influence of the commercial center on the north-south axis and new commercial areas began to emerge parallel to the coast. After the 1980s, and today, the parallel growth of the city on the east-west axis continues (Figure 24).

Figure 23, 24. The development direction of the commercial center and administrative center (Prepared by the authors)

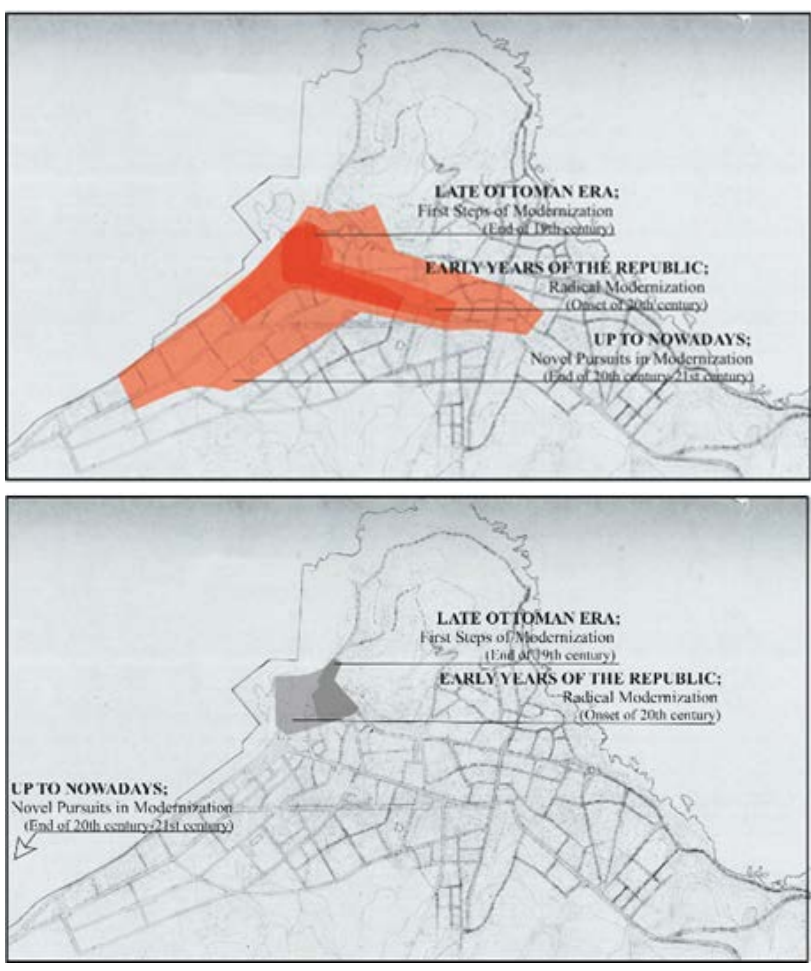




\section{The Effect of the Administrative Center on the General Development of the City}

It can be stated that the dual order and topographical data created by the municipality-oriented commercial center and the government houseoriented administrative center in the Late Ottoman Era was decisive in the macroform of the city. While the city center generally develops on the route surrounding the Giresun Castle, the city was spatially limited to the Kumyalı District where the Armenian citizens live, Gogora and Lonca districts where the Greek citizens live, and Sheikh Keramettin District where the Muslim citizens live.

In the city, in the first years of the Republic, it is seen that the existing ones were evaluated rather than the construction of a new one. The main determinant of the urban macroform, which showed a parallel development with the commercial center, was the construction of the highway and the port at the end of the 1950s. After 1980, the city mostly spread on the east-west axis, but also on the north-south axis, continuing the tradition inherited from the Late Ottoman Era. The main determinant of the urban macroform in the 1980s was that Fiskobirlik and Seka, which increased their trade volume, and supported the urban space with various units. The construction of the Fiskobirlik-Seka industrial campuses and the housing need of the city, whose population increased with the migration of both workers in these industrial buildings and from the villages, caused the opening of new residential areas and the expansion of the city's borders. These developments required the formation of new streets such as Yeniyol and Cemal Gürsel Street, and new districts such as Teyyaredüzü and Gemilerçekeği (Figure 25).

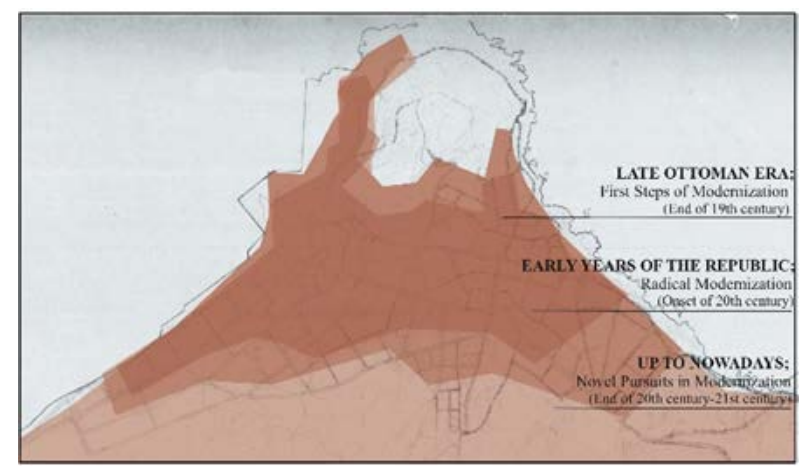

Figure 25. The urban macroform (Prepared by the authors)

\section{CONCLUSION}

This study discusses the modernization experience of one of Anatolia's coastal cities from past to present via other structures that define the city's Government House and Administrative Center. Apart from the general trends in Anatolia, it can be said that the local values of the city were determinant in defining this process. Although many of the buildings that define the administrative center of the late Ottoman Empire cannot exist with the same functions today, they are considered to be an important part of social order, although they have different semantic and functional expansions. The fact that they were built as parts 
of a whole, changed their functions or were demolished, bears the traces of the modernization experience, changing spatial order, and life practices of the city at different times. In other words, they are similar in that they were built as the epitome of every building period from past to present. However, they differ in terms of the requirements of the period they were in.

Recently, the increase in commercial units in the food and beverage areas and the connection roads built at the bottom elevation of the Government House made the administrative center an extension of the commercial center. They may not have the semantic and spatial power of the time when they were constructed as modern city images, but they continue to be a part of urban life in their region with the new functions they are given. Every architectural structure that creates the city takes part in the collective memory of the city, not with their singular identity but with their plural identities formed by the unity of historical layers. However, it is necessary to be aware of the fact that changes are made in the urban identity while constructing, changing functions of and demolishing these structures, and decisions should be taken by plural statements that are rational, comprehensive, and that will preserve the historical continuity of the city beyond the arbitrary decisions taken by random and singular actors.

For this reason, it is necessary to be aware of what the Giresun Government House, which is on the verge of being used as a city museum, tells us, and what kind of story it has. The Giresun Government House is the symbol of the modernization and progress in both the spatial and life practices of the city from the Late Ottoman Era to the Early Republic and today. It is not known how it will continue its modernization story from now on, but despite all the functional and temporal changes it will go through, it will continue to watch over the city from the top view on the skirts of the castle. However, apart from the singular value of the Government House, the spatial value defined by the coexistence of the administrative center with other structures should not be ignored. For this reason, at the point of making decisions regarding buildings, both local Governments central institutions, and conservation boards should evaluate architectural structures as parts that do not define the whole to which they belong, and develop an understanding, policy and implementation system for this matter.

\section{FINANCIAL DISCLOSURE}

The authors declared that this study has received no financial support.

\section{ETHICS COMMITTEE APPROVAL}

Ethics committee approval was not required for this article.

\section{LEGAL PUBLIC/PRIVATE PERMISSIONS}

In this research, the necessary permissions were obtained from the relevant participants (individuals, institutions and organizations) during 
the survey, in-depth interview, focus group interview, observation or experiment.

\section{REFERENCES}

Anonymous (1933). Cumhuriyet'in on yılinda Giresun (1923-1933). Giresun Ticaret ve Sanayi Odası, Işık Publisher.

Anonymous (1973). Cumhuriyetin 50. yılında Giresun. Giresun İl Yıllığı, Governorship of Giresun Publications.

Aslanoğlu, İ., İdil, B., İnan, U., Karaaslan, M., Ortaylı, İ., Özbek, N., Yatman, A. (1984). Osmanlı'dan bugüne hükûmet konakları (Causerie) Güven Birkan (Chair), Mimarlık, 203 (5), 3-5.

Avcı, Y. (2017). Osmanlı hükümet konakları. Türk Tarih Vakfı Yayınları.

Balcı, S. (2012). Giresun Rumları ve Gayrimüslim bir belediye başkanı. Libra Publications.

Bekdemir, Ü. (2015). İmar Çalıșmaları, Ulașım, Afetler ve Çevre Sorunları. In Bekdemir, Ü. and Fatsa, M. (Eds.). Geçmişten günümüze Giresun, Giresun İl Özel İdaresi Kültür Serisi.4 (pp. 250-278). Mavi Ofset Publisher.

Çadırcı, M. (1997). Tanzimat döneminde Anadolu kentlerinin sosyal ve ekonomik yapısı. Türk Tarih Kurumu Publications.

Çelik, Z. (2012). Imparatorluk, Mimari ve Kent, Garanti Kültür Publications.

Çetin, S. (2012). Geç Osmanlıdan Erken Cumhuriyete İç Batı Anadolu'da kentsel yapının değişimi: Manisa, Afyon, Burdur ve Isparta kentleri üzerine karşılaştırmalı bir inceleme, METU JFA 29(2), 89-126.

Düzenli, H.İ. and Taşar, E.S. (2012). Mardin'de Tarih, Bina ve Mimarlık Katmanları:19. yy. Hükümet Konağından 21. yy. Mimarlık Fakültesine Dönüşümün Hikayesi, Arredamento Mimarlık, 2012(2), 64-78.

Ersoy, A. (2009). Melezliğe Övgü; Tanzimat Dönemi Osmanlı Kimlik Politikaları ve Mimarlık, Toplumsal Tarih (189), 62-67.

Emecen, F. (1997). Giresun tarihinin bazı meseleleri, In Giresun Historical Symposium Proceedings Book (pp.19-24). Önder Publications.

Fatsa, M. and Sarıtaş, H.İ. (2012). Giresun merkezde Osmanlı Devri Vakıf Eser Kitabeleri, Vakıflar Dergisi, 38, 141-155.

Göle, N. (2000). Melez Desenler. Metis Publisher.

Hanioğlu, M.Ş. (2016). Modern Osmanlı Dönemi, In Heper, M. and Sayarı, S. (Eds.). Dünden bugüne Türkiye tarih, politika, toplum ve kültür, (pp. 1726). Bilgi University Publications.

Mardin, Ş. (1999). Türk modernleșmesi. İletişim Publisher.

Işık, A. and Dervişoğlu, T., (2011). Ey Gidi Giresun. Özyurt Publisher.

İltar, G. (2014). Giresun Kültür Envanteri, Giresun Valiliği Yayınları, Dönence Publications.

İnalcık, H. (1962). Sened-i İttifak ve Gülhane Hatt-ı Hümayunu, Türk Tarih Kurumu; Belleten Dergisi, 112, 603-622. 
İnsel, A. (2001), Modern Türkiye'de siyasi düşünce, Kemalizm. İletişim Publications.

Kabacaoğlu, G. and Dervişoğlu, T. (2019). Giresun Belediyesi ve Belediye Başkanları 1896-2014, Balcı, S. and İltar, G. (Eds), Giresun Belediyesi Publications, Çınaray Publishing.

Karaman, O. (1999). Giresun Kazası (1850-1900) [Doctoral thesis, Atatürk University Institute of Social Sciences]. Erzurum.

Karaman, O. and İltar, G., (2008). Giresun Üniversitesi rektörlük binasının tarihçesi, Giresun Üniversitesi Dergisi, 1, 21.

Kılıç, D. and Topal, İ. (2004). Salnamelerde Giresun'un sosyal ve dini yapısı (1869-1905), Karadeniz (Black Sea-ЧерноеMоре), 3 (12), 63-79.

Mercan, M. (2009). Giresun Telgraf Dairesi ve Telgrafhane Binası (1869 1904), The Journal of International Social Research, 2(7), 159-174.

Ortaylı, İ. (2008). Osmanlı İmparatorluğu'nda İdari modernleşme ve mahalli idare alanındaki gelișmeler, In Osmanlı'da değișim ve anayasal rejim sorunu, Seçme eserleri, II (pp. 263-277). Türkiye İş Bankası Publications, Turhan Publications.

Osmay, S. (1998). 1923'ten Bugüne kent merkezlerinin dönüşümü, In 75 yılda değişen kent ve mimarlı (pp. 139-155). Tarih Vakfı Publications.

Sunay, S. (2018). Son dönem Osmanlı taşra hapishanelerine bir örnek: Bolvadin Hapishanesi, Afyon Kocatepe Üniversitesi Sosyal Bilimler Dergisi, 20(1), 43-66.

Tekeli, İ. (1985). Tanzimat'tan Cumhuriyet'e kentsel dönüşüm, In Tanzimattan Cumhuriyet'e Türkiye Ansiklopedisi III (pp. 878-890).

Usta, V. (2011). Müdafaa-i Hukuk ve İstiklal Harbi tarihinde Giresun, Osman Fikret Topall, Serander Publications.

Usta, V. and Çulfaz, M. (2017). Müdafaa-i Hukuk ve Ístiklal Harbi tarihlerinde Giresun: Milli Mücadele günlerinden izler, intibalar, notlar, Serander Publications.

Umar, B. (1981), Eski Eserler Hukuku, Ege University Publications.

Yazıcı, N. (2014). Osmanlı mimarlığında bir yönetim binası örneği: Canik/Samsun Hükümet Konağı, In Şahin,İ., Egawa, H. (Eds.). CIEPO19Osmanlı öncesi ve dönemi tarih araştırmaları (pp. 313-328). İstanbul Esnaf ve Sanatkarlar Odaları Birliği Publications.

Yerasimos, S. (1999) Tanzimat'ın Kent Reformları Üzerine, In Dumont, P. and Georgeon, F. (Eds.). Modernleşme sürecinde Osmanlı kentleri (pp. 119). Tarih Vakfı Yurt Publications.

Yeşilgiresun Newspaper, 5th September 1969, Giresun.

Yeşilgiresun Newspaper, 19th June 1920, Giresun.

Yüksel, A. (1997). Salnamelere göre Giresun bölgesinin idari durumu ve idarecileri, In Giresun Historical Symposium Proceedings Book (pp. 173189). Önder Publications.

Yüksel, A. and Yeşilot, O. (2016). Giresun'da findık ve Fındık Borsası'nın tarihçesi, Öncü Gazetesi Publications. 


\section{Resume}

Selin Karaibrahimoğlu graduated from Gazi University, Department of Urban Planning in 2002. She has received her master's degree from Çankaya University, Department of Interior Architecture. She received her PhD Karadeniz Technical University, Department of Architecture. Since 2015 she has been working as an assistant professor at the Giresun University.

Özgür Demirkan graduated from Karadeniz Technical University, Department of Architecture in 2001. She has received her master's degree from Karadeniz Technical University, Department of Architecture. She received her PhD Karadeniz Technical University, Department of Architecture. Since 2012 she has been working as an assistant professor at Giresun University. 